Bob had some degree of impact on almost every person with a passion for carnivorous plants. His love of CP and the Carnivorous Plantation he so carefully cultivated are his legacy, and I am sure there will be plants growing 50 or even 100 years from now that would never exist were it not for Bob Hanrahan. I surely do hope that the "better place" we are all supposed to go to one day will be hot and humid with towering afternoon thunderstorms and Sarracenia stretching out as far as the eye can see.

\title{
ERRATUM \\ THE CORRECT NAME FOR THE HYBRID BUTTERWORT PINGUICULA GRANDIFLORA SUBSP. ROSEA $\times$ P. VULGARIS
}

\section{JAN SCHLAUER・jan@carnivorousplants.org}

Aymeric Roccia (2013) described a new hybrid butterwort from the Alps of Isère, SE France. Unfortunately, the present author did not have a chance to review the manuscript before the article went to print, so a nomenclatural problem was overlooked. The new hybrid involves a subspecies different from the type subspecies of Pinguicula grandiflora (viz., P. grandiflora subsp. rosea) as a parent, while the analogous hybrid of the type subspecies of $P$. grandiflora was already described earlier under the legitimate name $P . \times$ scullyi (Druce 1922). The new hybrid can thus not receive a name different from $P . \times$ scullyi at species rank as originally proposed by Roccia ( $c f$. ICN, Art. H.5.2. "If the postulated or known parent taxa are of unequal rank the appropriate rank of the nothotaxon is the lowest of these ranks", McNeill et al. 2012). Subspecies rank is appropriate in the present case, and the formally correct name is:

Pinguicula $\times$ scullyi nothosubsp. gresivaudanica (Roccia) J. Schlauer comb. \& stat. nov.

Basionym: Pinguicula $\times$ gresivaudanica Roccia, Carniv. Pl. Newslett. 42(2): 37 (2013)

\section{References:}

Druce, G.C. 1922. Secretary's Report for 1922. The Botanical Society and Exchange Club of the British Isles 6: 159.

McNeill, J., Barrie, F.R., Buck, W.R., Demoulin, V., Greuter, W., Hawksworth, D.L., Herendeen, P.S., Knapp, S., Marhold, K., Prado, J., Prud'homme van Reine, W.F., Smith, G.F., Wiersema, J.H., and Turland, N.J. 2012. International Code of Nomenclature for Algae, Fungi, and Plants (ICN, Melbourne Code). Regnum Vegetabile 154. Koeltz Scientific Books, Koenigstein, Germany. Roccia, A. 2013. Pinguicula $\times$ gresivaudanica (Lentibulariaceae), a new butterwort hybrid from the

French Alps. Carniv. P1. Newslett. 42(2): 36-46. 